\title{
AC 2011-819: ENGINEERING ENTREPRENEURSHIP: LEARNING BY DOING
}

\section{Erik Sander, University of Florida}

Erik Sander began his career as a Project Manager and Senior Engineer analyzing advanced fighter aircraft engines and the Space Shuttle Main Engine for NASA, Lockheed Martin, General Electric, and Pratt \& Whitney. He was also a Technology Transfer Officer for Lockheed Martin and the NASA Marshall Space Flight Center. Starting in 1995, Erik joined the faculty of the University of Florida College of Engineer as Director of the University Center, Associate Director for the Engineering Research Center and the Florida Energy Systems Consortium, and Director of Industry Programs - all directed at fostering industrial collaboration, entrepreneurship, and technology commercialization across a \$100M research base. He also manages the UF-High Tech Corridor research fund, providing investments in high tech company R\&D collaborations. Erik was a Principal for Cenetec Ventures, a private technology incubator and early stage venture fund and, along the way, he grew several start-up companies in areas ranging from real estate development to technology deployment. From 2005-2009, Erik served as President of V2R Group, a university technology commercialization company that provides funding and executive level services to growing companies in markets from information technologies to medical devices. Erik serves as a professor of entrepreneurship at the graduate level for the University of Florida College of Engineering. 


\title{
Engineering Entrepreneurship: Learning by Doing
}

\begin{abstract}
$\underline{\text { Abstract }}$
The University of Florida College of Engineering offers an entrepreneurship course targeted to graduate engineering students and working professionals of all engineering disciplines which mimics, as completely as feasible in an academic environment, the real world experiences of enterprise formation and growth. The course structure includes executive team formation, building the company, and fundraising through multiple capital rounds. Each graduate engineering student takes dual roles of company executive and technology investor. Participants invest in each other's enterprises at valuations negotiated between the students themselves as both investors and entrepreneurs. Critically, at the end of each semester, external investors and serial entrepreneurs review final presentations and "acquire" each student company, providing a Return on Investment for each student as a technology entrepreneur and also as a technology investor based on dilution through three rounds of fundraising and company acquisition terms. Lessons learned are explored to provide for instructive advice to others who may wish to explore a similar offering.
\end{abstract}

\section{Background / Motivation}

Engineers have taken their rightful place as technology entrepreneurs over the last few decades and their impact to the world's economy and standard of living have been tremendous. While entrepreneurship had traditionally been thought of primarily as the purview of those who came from business oriented education and careers, the advent of enabling technologies such as the internet, microelectronics, nanotechnology, advanced instrumentation and sensing systems, and understanding of the human being have opened new opportunities for discovery and innovation that play to engineers' strengths. Technological advances and entrepreneurship, spurred by entrepreneurial education, are truly changing our world's standard of living and global economy. ${ }^{\text {i }}$

Generally speaking, engineers often have characteristics that provide a strong foundation as entrepreneurs:

- Engineers are trained to be analytical problem solvers, creating practical solutions from new ideas. Engineers translate discovery to practice.

- As highlighted by the National Academy of Engineering, engineers attack the world's most daunting problems requiring cross-disciplinary solutions. These include "making solar energy economical, providing energy from fusion, developing carbon sequestration methods, managing the nitrogen cycle, providing access to clean water, restoring and improving urban infrastructure, advancing health informatics, engineering better medicines, reverse-engineering the brain, preventing nuclear terror, securing cyberspace, enhancing virtual reality, advancing personalized learning, and engineering the tools of scientific discovery. ${ }^{\text {,i }}$

- Engineers are entrepreneurial leaders as illustrated by a recent Kauffman Foundation study on leading entrepreneurial companies showing that founders with engineering degrees, and more generally STEM disciplinary training, have proven their mettle as successful entrepreneurs. In this study, $28 \%$ of US born tech founders of successful companies in the study held engineering terminal degrees. ${ }^{\text {iii }}$ 
At the same time, engineers face substantial challenges in transitioning to the world of innovation champions (entrepreneurs and "intrapreneurs") such as:

- An engineering education is typically focused on technical depth rather than breadth in fields such as business practice, accounting and finance, operations management, etc. Additionally, the historical engineering curriculum has not included a substantial component of "soft skills" such as ethics, persuasive communications, written and oral presentations, team building, crisis management, and the other skills necessary to succeed as an entrepreneur, the value of which have been recognized by ABET and other organizations. ${ }^{\text {iv, v }}$

- An engineering education typically does not provide sufficient opportunity to lead teams, communicate ideas, understand and exercise real world ethics in challenging situations, and experience other "real-world" dilemmas faced by innovators.

The University of Florida College of Engineering (UF COE) has depth in education and research across a broad spectrum of disciplines with 11 departments, over 270 faculty members and over $\$ 100 \mathrm{M}$ in annual research expenditures. The COE has recently engaged in a strategic planning process which reinforced that the college is well positioned to provide students and faculty with a full innovation educational experience as the College is:

- Comprehensive, as the 14th largest school of engineering in the US in undergraduate enrollment and $6^{\text {th }}$ largest in graduate enrollment ${ }^{\mathrm{vi}}$, with $\sim 8,300$ students and virtually every major engineering discipline represented.

- Interdisciplinary, as the COE Strategic Plan, of which entrepreneurship education is a key component, focuses on discovery and innovation at the intersection of traditional technology disciplines.

- Collaborative, operating in a university recognized as a national technology commercialization leader ${ }^{\mathrm{vii}}$ and one of the largest in the country in terms of size and number of disciplines.

UF includes colleges of engineering, medicine, food and agricultural sciences, liberal arts and science, and business, along with a host of other units on a single campus - providing a strong and diverse collaborative environment. Innovation is happening at the intersection of technology disciplines and UF provides an innovative ecosystem in which the COE entrepreneurship education programs can flourish.

Against this backdrop, in 2003 the COE, in collaboration with the UF Warrington College of Business Administration / Center for Entrepreneurship and Innovation (CEI), created a foundational entrepreneurship course exclusively focused on graduate students of all engineering disciplines. This course was initially created and supported by both the Warrington College of Business Administration and College of Engineering as it complements the many other entrepreneurial offerings of CEI, while providing engineering students a focused entrepreneurial education experience that provides a high level of technology development and market application strategy. Studies show that combinations of classical teaching and experiential methods such as business plans, consultations with start-up entrepreneurs, computer and behavioral simulations, and published or live case studies are effective in entrepreneurship education. ${ }^{\text {vii, ix, } x}$ The UF College of Engineering entrepreneurship course was designed to leverage these advantages by providing a "real world" entrepreneurial experience within the safe 
confines of the student's learning environment, an established and impactful teaching methodology. ${ }^{\mathrm{xi}}$, xii

In 2009, the College of Engineering started to deliver the course to working engineering professionals through the college's distance education program, Electronic Delivery of Graduate Engineering (www.ufedge.ufl.edu).

In 2010, the COE started to design the University of Florida Engineering Innovation Institute to foster a culture of innovation among faculty, students and staff. The Institute serves as a nexus of engineering innovation education and experiential programs extending across the spectrum of creative discovery and invention, to the transition of UF Engineering technologies and innovative students to the marketplace. The Institute aims to produce leaders with engineering and innovation skills to attack the world's most daunting problems and change the world. The Institute's primary program elements are creativity and entrepreneurship built on the foundation of the COE's research programs. The College's inter-disciplinary research institutes, and its broad spectrum of Departments and Schools, provide a unique platform upon which creativity and entrepreneurship education will produce many of our next generation innovation leaders, whether they work in the private, academic, public service, non-profit, or government/military sectors. The Institute's creativity element aims to develop innovative thinking in our constituents, providing invaluable skill sets when combined with the analytical and problem solving skills inherent in our engineering education and research programs. The entrepreneurship element focuses on dovetailing technology with entrepreneurial education programs and is designed to bring commercialization focus and direction directly to the breadth and depth of the COE's research programs, ingraining entrepreneurial thought processes in engineering students and faculty. Fostering a culture of innovation in a broad and powerful engineering college will lead to significant impact on the rate of technology transfer to the public sector.

It is in this context that the COE is expanding its entrepreneurial curriculum offerings as outlined below based on its foundational entrepreneurship course, Entrepreneurship for Engineers.

\section{Entrepreneurship for Engineers}

Entrepreneurship for Engineers (E4E) is targeted to graduate engineering students and working professionals of all engineering disciplines and mimics as completely as feasible in an academic environment the real world experiences of enterprise formation and growth. The course structure includes executive team formation, building the company, and fundraising through multiple capital rounds. Each graduate student takes dual roles of company executive and technology investor. Participants invest in each other's enterprises at valuations negotiated between the students themselves as both investors and entrepreneurs. Critically, at the end of each semester, external investors and serial entrepreneurs review final presentations and "acquire” each student company, providing a calculated Return on Investment (ROI) for each student as a technology entrepreneur and also as a technology investor based on dilution through three rounds of fundraising and company acquisition terms.

E4E is designed to introduce engineering graduate students of all disciplines, company engineers, and engineering managers to the concepts and practices of entrepreneurial thinking 
and entrepreneurship through an immersive, real world entrepreneurial experience. Using a combination of lectures, case studies, team business plans, and investor presentation formats, the course teaches life skills in entrepreneurial thought and action that students can utilize in careers ranging from starting companies to planning and executing high risk R\&D projects in large companies. The course is firmly presented in a "real-world" format, including students taking the roles of company founders and investors, creating a vision and execution plan for their company, and raising funds - exactly as they would in a true entrepreneurial endeavor.

Major Course Themes include:

- Introduction to entrepreneurship and entrepreneurial thought processes

- Entrepreneurial idea generation and feasibility analysis

- Entrepreneurial business development (market analysis, product development, marketing, operations, HR, legal, intellectual property, accounting, capitalization, etc.)

- Business planning and execution

Student Learning Objectives include:

- An understanding of the basics of entrepreneurship and entrepreneurial thought processes

- Team-based, real-world experiences in working as an entrepreneurial executive team to explore entrepreneurial processes including building and executing on a business plan

- Project planning and presentation skills through teaming experiences

E4E is organized around lectures, readings, class discussion and a team project. Students organize into virtual companies (teams) for the purpose of developing a venture idea into an early stage business plan and presenting that plan. This is a well exercised and valued model in entrepreneurship education. ${ }^{\text {xiii }}$ Importantly, students self-select into executive teams of typically 4-5 students at the beginning of the semester. Students share biographies in the first two weeks of the semester that allow them to learn about each other.

Each student assumes the role and responsibilities of a start-up company executive (e.g. Chief Executive Officer, Chief Technology Officer, Chief Operating Officer, and typically a Chief Business Office or Director of Marketing or Business Development). Students are held responsible for duties traditionally associated with those roles throughout the semester. Additionally, starting in 2010 the UF COE Entrepreneur-in-Residence has acted as the Chairperson for each virtual start-up company providing weekly guidance to the company executives.

The deliverables for each team are individual elements of a business plan and a team presentation of the plan to the class and external executives (serial entrepreneurs and investors) that the instructor engages. The final exam consists of an individual assessment of an entrepreneurial case study.

Of critical importance in development of the instructional pedagogy is the foundational strategy that assignments build on each other. The class is structured so that the students form executive teams of virtual start-up companies and develop a business plan, investor presentation, and collateral materials (e.g. market research reports, company web sites, marketing materials, etc.) used to coalesce all of the key lessons of the course. Information on the following topics are 
delivered, reinforced, and exercised by the students through a combination of instructor lectures, guest lectures by entrepreneurs from different fields ranging from no-tech to high-tech, and classroom exercises of business plan element presentations. These presentations are designed to challenge the student to clearly and persuasively communicate their company vision (value proposition presentation), execution strategy (operational strategy / financial projections), and opportunity summation (final investor presentation) to their fellow students, guest reviewers, and the instructor. Strategically, the building of a business plan by each virtual start-up company is a means to an end as much as it is an end in itself. The business plan structure is used to introduce and integrate the major instructional elements / lectures presented.

The Course Structure includes:

- Introduction to Entrepreneurship - Students are introduced to the basic concepts of entrepreneurship and specifically how technology-based entrepreneurs have changed the world over the last 50 years and current/future trends in technology entrepreneurship.

- Attributes and Myths of Entrepreneurs - This topic debunks some of the commonly held myths of entrepreneurs (i.e. Entrepreneurs are wild-eyed risk takers, Companies are typically founded with millions in venture capital, etc.) and explores the positive and negative attributes of technology entrepreneurs.

- Engineers and Entrepreneurship - The role of engineers as successful entrepreneurs is discussed based on studies of groups such as the Kauffman Foundation and others.

- The Mindset of the Entrepreneurial Leader - The entrepreneurial leader's mindset, motivation, fears, and other attributes are studied to gain a better understanding of what drives a technology entrepreneur to success - or failure.

- Creating and Selling the Value Proposition - Students explore the concept of defining and selling their company's Value Proposition - the economically substantial need that they can uniquely solve with a business model to create value.

- Capital Raising and Valuation - Students are introduced to the subjects of value creation for myriad stakeholders (investors, executives, employees, customers, etc.), capturing that value through valuation models, and raising capital through investment vehicles skills that they will exercise in the course Student Investment Forums.

- Ethics - Students are introduced to the ethical challenges that engineers and entrepreneurs will most likely face in the course of their careers and the criticality of making informed and sound decisions in the face of what are sometimes gray areas.

- Persuasive Communications - Students learn the value of effectively communicating their vision and execution strategies and results at multiple points during the course - and receive immediate, quantifiable feedback on their performance as persuasive communicators through the Student Investment Forums and final presentation and Company Sale.

- Entrepreneurial Opportunity Feasibility Analysis - Students challenge their own technology ideas through a vetting process which includes market assessment, competitive analysis, regulatory screening, financial screening, customer analysis, and other aspects of entrepreneurial opportunity feasibility analysis.

- Presenting the Opportunity - Students are introduced to and exercise strategies and tactics in persuasively presenting their company value proposition, vision, and execution plan to investors and other stakeholders. 
- Starting the Business / Company Formation Strategy and Structure - Advantages and disadvantages of entrepreneurial entity structures are explored, compared, and contrasted and key strategies and tactics in company formation are discussed.

- Business Planning and the Business Plan - The process of business planning is outlined and the elements of a business plan and presentation are outlined as students prepare their company plans.

- Market Research and Competitive Analysis - Students are introduced to strategies and tactics in understanding target markets and competitive forces from perspectives of publicly accessible information to "guerilla market research."

- Business Plan Financials - The entrepreneurial Balance Sheet, Income Statement, Cash Flow Statement, Budgets, and Pro-formas are explored from a rudimentary level.

- Intellectual Property Strategies and Management - Strategies and tactics related to patents, copyrights, trademarks, service marks, trade secrets, and other forms of knowledge capture are explored as students learned about intellectual property management.

- Building a Winning Team - Students gain an understanding of team and individual characteristics that can drive success and how those attributes change through the life cycle of a start-up company.

As one might expect, assessment of student progress and grade assignment is very qualitative compared to the more quantitative assessments in a traditional engineering course - and is challenging for the instructor. Students are given all assignments for the course, including the final exam, at the beginning of the semester in order to understand how each assignment builds off of previously introduced materials and in order to prepare in advance for their final presentation and plan. The overall student assessment and course grade is given based on a combination of individual assignments and team (company) assignments, with increased emphasis on company assignments toward the end of the semester as the student teams (company executive teams) coalesce.

Individual assignments comprise 35-60\% of each student's final grade and consist of an Individual Idea Overview, two case analyses based on the movie Startup.com, and course participation as assessed by contributions to their company, class discussions, discussion boards, etc. The students have the option to submit the two case analyses as a team (company) assignment if every student on the team chooses to do so. This provides an indication of the strength of the team.

Team assignments comprise 40-65\% of each student's final grade and consist of a Company Idea Overview and presentations of the company Value Proposition, Financial Analysis, and Business Plan. Experience shows that the stronger teams will choose to submit the two case studies as a team rather than individually. Sample assignments are provided in Appendix A.

The instructor relies heavily on current events in entrepreneurship as reported in appropriate media such as national newspapers, journals, and web sites rather than on multiple traditional text books to fortify the classroom instruction and add real life context to learning goals. The course utilizes electronic communications (e.g. bulletin board and list serve) for students to share and discuss current events that relate to classroom discussions. 


\section{$\underline{\text { Student Investment Forum }}$}

A key element of Entrepreneurship for Engineers is an opportunity for students to act as technology investors as well as technology entrepreneurs through the course's Student Investment Forum. In the Student Investment Forum, students take investment in their companies and invest in each other's companies at three points during the semester in which they have the opportunity to present to their student colleagues:

1. Early in the semester when they present their company vision and value proposition

2. Midway through the semester when they present their company execution plan and financial projections

3. Late in the semester when they present their company summation through a business plan presentation

The presentations above provide each company executive team with a chance to gage their performance and company attractiveness compared to the other companies in the course at three points in the semester. Typically 7-9 companies are formed each semester and each student executive team (comprised of 4-5 students) must determine their relative attractiveness for "investments" against the other companies. Immediately following each set of presentations above, each company offers equity at pre-money valuations/share prices that they negotiate with the other students in the course, who are given "funds" for investment in each other's companies. This is a very dynamic process as students:

- Acting as entrepreneurial executives, are competing against the other student companies in the class and must raise or lower their valuation to attract sufficient funds for each capital round as determined by the instructor

- Acting as technology-company investors, are gaging the potential of each other company in the class as the best vehicle to grow their Return on Investment based on what they perceive to be the inherent value in the company and team and the valuation / share price at which equity is offered.

Each company must raise equal amounts of investment from other students in the course as determined by the instructor over the semester, students can invest in other companies, but not in their own company, and students must invest in minimum amounts (investment units).

Critically, the instructor also holds certain investment units (typically $~ 30 \%$ of the class total) for investment to close investment rounds.

The instructor has found the Student Investment Forum to be not only an exciting means to teach and demonstrate value creation, but also an invaluable learning experience as company

executives (students) learn from other students as well as from the instructor how well they have delivered their messages (vision, execution strategy, opportunity) based on the valuation / share price at which they were able to get investor interest. Companies that are forced to raise funds at a relatively low valuation / share price, and experience the subsequent relatively high dilution of ownership receive a clear and quantifiable message that their performance or company idea is not up to snuff. Alternately, those that present their opportunity, vision, and execution plan well are rewarded through high investment round valuations and minimized equity dilution. Students capture these results through issuance of equity (shares) and company capitalization tables are maintained by each company CFO. Companies then have shareholders (the other students that 
are investors in their companies) with whom they must communicate company progress and major direction changes - again mimicking real world entrepreneurship to as great a degree as possible.

All company capitalization tables, including shares issued and investments made by each student, are compiled in one course capitalization table kept by the instructor for subsequent Return on Investment calculations. Appendix B contains an example course capitalization table.

During the last class period of the semester, the student executive teams deliver an investor presentation to external entrepreneurs and investors (angels and venture capitalists) brought in by the instructor. While mock investor presentations to outside professionals who "judge the results and declare a winner" are relatively common for entrepreneurship courses, in E4E the outside investors deliver their judgment through valuations at which they "purchase" all outstanding shares of each company, within a valuation collar as determined by the instructor. This strategy has two advantages over traditional approaches:

1. Student executive teams are provided with an external quantitative assessment of the perceived relative value of each company against all others through the purchase price of each company.

2. Each executive team is instantly provided with a Return in Investment (ROI) for 1) the students as company founders, and 2) the students as technology investors in each other's companies.

Specifically, each company's final purchase price combined with the equity dilution experienced by each company executive team and student investors through the three Student Investment Forum rounds will determine an ROI for each company and each student investor. This is immediately calculated using the class capitalization table as the external professionals provide their company purchase prices in the last class of the semester. Each company executive of the company with the highest ROI for its founders' initial investment in their own company receives an A for the course irrespective of their assignment grades throughout the semester and is excused from the final exam. Similarly, the two students with the highest ROI for their investments during the semester in other companies are similarly rewarded. This rewards students that are able to perform exceptionally by building and demonstrating company value through the semester (through minimizing dilution through three fundraising rounds) and finishing strong through attracting a high sales price for their company. Similarly, the process rewards students as investors who can recognize entrepreneurial value in other companies and executive teams.

\section{$\underline{\text { Course assessment }}$}

This course has been offered to graduate students from all engineering departments, and working engineering professionals through distance education, since fall 2003. In that time timeframe, over 500 graduate engineering students have taken the course, which has typically been fully subscribed each semester. The university assesses each course at the end of every semester through various qualitative as well as 27 quantitative criteria and the results for this course from 2003-2010, given below, show that the course content and instruction methodology are 
considered to be of very high value by the students, being ranked well above the College of Engineering mean score in all 27 assessed categories.

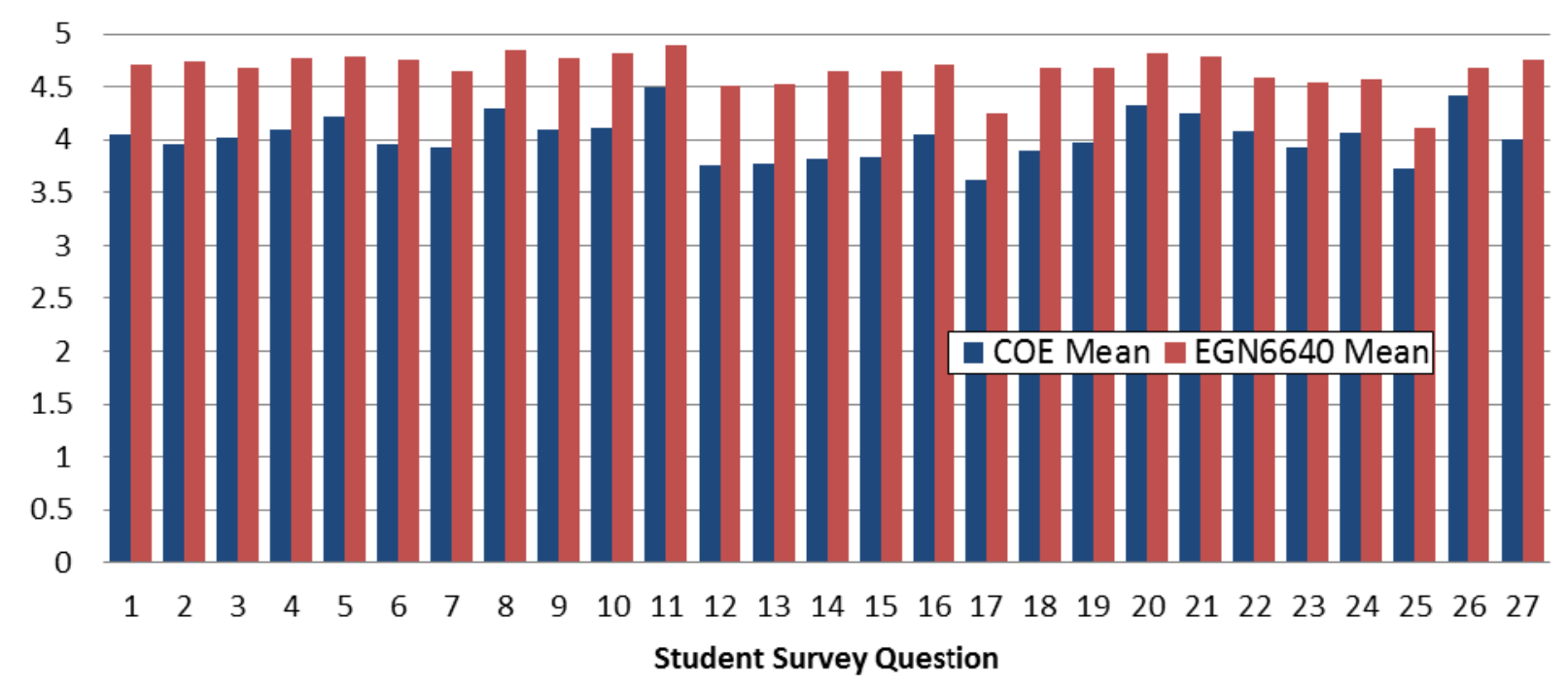

Figure 1 - Entrepreneurship for Engineers course assessment 2003-2010: Comparison to all College of Engineering course composite mean scores

Assessment Question Key

1. Description of course objectives and assignments

2. Communication of ideas and information

3. Expression of expatiations for performance in the class

4. Availability to assist students in or out of class

5. Respect and concern for students

6. Stimulation of interest in course

7. Facilitation of learning

8. Enthusiasm for the subject

9. Encouragement of independent, creative, and critical thinking

10. Overall, I rate this instructor as

11. Instructors knowledge of the subject was

12. Assignments and/or projects were

13. Testing procedures (quizzes, tests) were

14. Instructor's teaching methods were

15. My learning experience in this course was

16. Explanation of relevant practical applications was

17. Texts and other course materials were

18. Timeliness of homework, exam, project grading was

19. Fairness in grading was

20. Instructor's diligence in meeting class on time was

21. Instructor's diligence in ending class on time was

22. Extent to which basics of subject were covered was

23. The course syllabus was

24. Extent to which syllabus was followed was

25. Extent to which the textbook was followed was

26. Instructor's attendance was

27. The overall value of the course was

Additionally, the anonymous course assessment survey invites each student to provide comments regarding course structure and delivery. The common message from students is that this type of 
non-traditional course and real-world educational experience is highly valued and appreciated by the students. Of over 300 students who have provided comments in the survey, virtually all have indicated a high level of satisfaction and perceived value from this course and have an appreciation for the "real world" structure of the course.

The quantitative assessment mechanism and outcomes cited above can be skewed by a comparison of an elective course, which the students choose to take, against the overall engineering curriculum and the instructor is undertaking a deeper evaluation of the data to determine if more granular comparisons can be made. Additionally, as the course is highly team-oriented, the instructor is exploring means of assessing student learning outcomes through team-based learning models. ${ }^{\text {xiv }}$

\section{$\underline{\text { Lessons learned }}$}

Valuable lessons have been learned from delivering engineering entrepreneurship education through the learning-by-doing methodology described above. These lessons can inform others who wish to explore this instructional pedagogy or utilize elements of this course structure in their own educational environments. Some primary lessons learned include:

Overall Course - This type of high-touch, real-world course has advantages and disadvantages that impact potential expansion of this offering and how it may provide value to other engineering entrepreneurship educators:

- Grading is challenging as assignments are typically very qualitative and this is a completely new topic to the students. The qualitative nature of this course is divergent from much of the rest of their graduate engineering educational program and the instructor must balance the student's lack of any experience in this area with the high expectations and pace of the course.

- Getting the students to think big and tackle problems that will change the world can be a challenge. Students many times will want to form their companies around relatively simple ideas (e.g. web sites that deliver a limited service) rather than larger ideas that can change the world as they are looking to control the perceived risk of developing a business plan on which they might not be able to deliver around a world-changing idea. Additionally, this course combines students from different engineering disciplines into company executive teams, who then many times choose relatively simple ideas with which all team members can feel comfortable. The instructor must constantly challenge the student teams by insisting that they choose ideas that can change the world to get the most of their educational experience in this course.

- A high level of discussion and interaction through electronic means (bulletin boards, list serves, etc.) stimulates the learning process. Utilizing current entrepreneurial events and articles excites students who see the real world relevance of the topics they're studying and get a better understanding of these events from what they're learning real-time in the course.

- Cultural diversity of students is helpful in stimulating learning. While this can be said of almost any educational program, it is especially relevant to this course as the diversity of experiences drives much of the executive team's discussions, especially in the level of risk to take in developing their products / services and execution strategies. 
- Scaling course enrollment while maintaining interactivity and experiential, small teambased activities is very difficult. This type of educational experience is very hands-on as executive teams will go down many paths as they develop their ideas and need constant guidance from the instructor. Additionally, experience indicates that the optimal size of a company executive team is 4-5 students. With several class sessions where all teams present as described above, a given course section can only accommodate a limited number of students.

- Distance education adds special challenges. E4E has been offered to working students through distance education only since 2009. However, in that time frame, certain challenges have become evident. Notably, distance education students many times choose not to work in teams due to their disparate locations and work schedules and so can't participate fully in all aspects of the course such as the Student Investment Forums. Each distance education student must build a company and business plan and so each student becomes the equivalent of their own company, greatly increasing the instructor work load. However, some distance education students have chosen to work in teams starting in the spring 2011 semester and present their opportunities to the class, through electronic means such as electronic video files sent to the instructor or YouTube videos. The true impact and challenges of these means are to be determined at this point.

- As the student teams progress through the course, the intrinsic value of the idea and the presentation of the idea are both critical. Student teams that start with mediocre ideas invariably suffer as their opportunities don't develop and the students lose excitement as their companies receive low valuations in investment rounds. Thinking big (Change the World ideas) and early vetting of the idea are critical. At times, teams may find that they need to change their company's foundational idea or technology as they learn more about the market, competition, etc. and this should be permitted.

- Adding a chairperson for each company has added a new dimension to the course. The College of Engineering Entrepreneur in Residence has substantial real-world entrepreneurial experience to share with the student teams, but the students need to be educated on the role of a chairperson as someone that will guide their team, and not a substitute for the instructor.

- Establishing long term assessment tools to monitor program performance and impacts will be critical as this and complementary courses as described below are started and expanded. The assessment survey for the course is valuable in providing real-time feedback and comparison to other College of Engineering and university courses, but does not provide for an assessment of longer term impacts to students.

Student Investment Forum and Company Sale - Arguably, the most unique aspects of this course are captured in the Student Investment Forum structure. As such, it's instructional to explore lessons learned specific to this educational methodology:

- While the Student Investment Forum has proven to be an excellent teaching tool, it is inherently an imperfect market because all students must invest and all companies must raise an equivalent amount of funds. Additionally, the limited time to close an investment round (the class period time remaining after company presentations) forces some decisions that are less than optimal. Student investors are being asked to make their investments on the limited information of the presentations as most do not have the time 
to research the market opportunities of all of the other companies in the course (their potential investment opportunities).

- Because of the imperfect nature of the Forums and the fact that students are smart and learn that they can force valuation drops by simply holding their investment funds, it is important that the instructor is provided with funds to close investment rounds.

- Valuation is a great mechanism for students to understand the impact of value creation to themselves and their shareholders. The instructor has found that students who are forced to lower their valuation / share price to attract investment because their foundational company idea or technology, or their presentation of their company opportunity, is substandard learn much from this experience.

- Students engage fully in the competitive process of the investment rounds, but students will also find ways around the system and are tempted to collude. Making students act as investors and entrepreneurs and measuring ROI on both helps to mitigate this.

- For the final class judges, putting acquisition prices on large vs. small opportunities is difficult when they are asked to make decisions solely on business plans and investor presentations. However, this is the nature of the course wherein teams with myriad potential market sizes, competitors, etc. are competing against each other.

\section{Looking forward}

Building on the success and impact of E4E and to foster a culture of entrepreneurship and innovation within the UF College of Engineering faculty and students, the college is planning to expand its engineering entrepreneurship education program by offering further curriculum and a Certificate of Engineering Entrepreneurship. The curricular elements of the Certificate are being designed to complement the course elements of E4E by delivering instructional material to develop the individual student (Engineering Leadership) and the student's target technology (Engineering Innovation) as outlined in Figure 2.

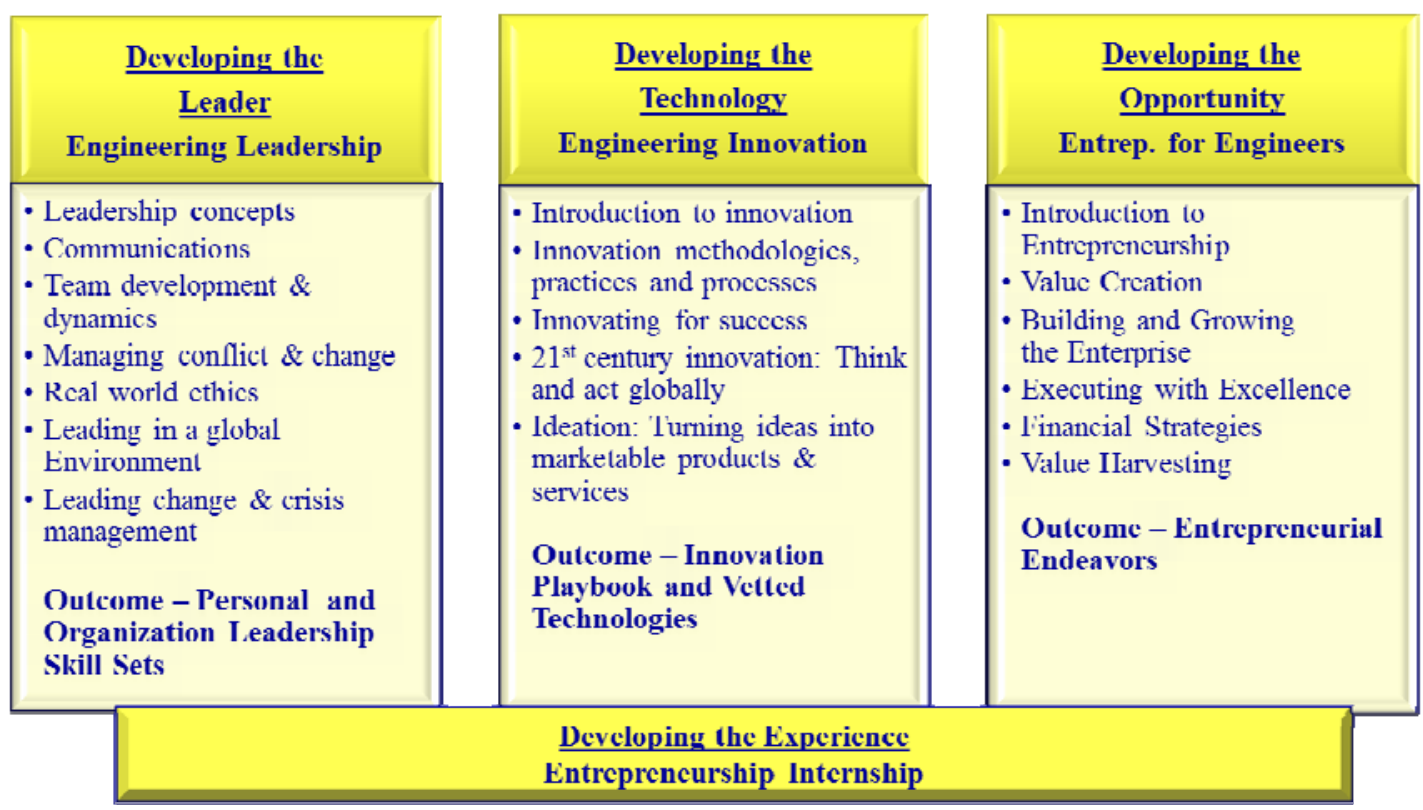

Figure 2 - Engineering Entrepreneurship Certificate Curriculum Overview 


\section{Conclusion}

The University of Florida College of Engineering has provided engineering graduate students from myriad disciplines with a foundational engineering entrepreneurship course since 2003. The instructional pedagogy is real-world based in that students are given the foundational entrepreneurship instruction by an experienced instructor and guest speakers, and the students form companies around technology ideas and go through many of the same experiences as young entrepreneurs as they build their companies. Students take the roles of entrepreneurial executives and investors as they experience multiple investment rounds in which they are measured by the instructor and other students in the class on the basis of their company opportunity and presentation skills. The instructional methodology has proven to be of high value to students and provides valuable lessons learned for expansion of the curriculum and for other engineering entrepreneurship educators who may wish to explore program elements. 
Appendix A

Sample Course Assignments

\section{Individual Idea Overview Assignment}

Your Idea Overview should provide an initial framework for expressing the salient points of your entrepreneurial idea of interest. This framework is designed so that you should be able to quickly and clearly explore and express the key aspects of your technology-based idea. As you proceed through this course, you'll expand this framework to a business plan summary in your journey to understand the entrepreneurial process. A key part of this journey is translating from the everyday questions that help you and others understand the potential opportunities inherent in your idea to the equivalent business plan terms as shown below:

\begin{tabular}{|ll|}
\hline Key Questions & Business Planning Equivalents \\
\hline Who are you? & Management Team; Strategic Partners; Advisors; Operation \\
\hline What are you planning? & Product / Service; Core Technology \\
\hline $\begin{array}{l}\text { Why can you do it better than } \\
\text { anyone else? }\end{array}$ & $\begin{array}{l}\text { Competitive Advantage; Distribution; Marketing; Position; } \\
\text { Operations Advantages }\end{array}$ \\
\hline $\begin{array}{l}\text { Who cares, why do they care, } \\
\text { and how much do they care? }\end{array}$ & $\begin{array}{l}\text { Market; Market Needs Analysis; Revenue Model; Pricing } \\
\text { Strategy }\end{array}$ \\
\hline $\begin{array}{l}\text { What do you need to get it } \\
\text { done? }\end{array}$ & $\begin{array}{l}\text { Investments; Strategic Partnerships; Operations; } \\
\text { Technologies, Distribution Channels, etc. }\end{array}$ \\
\hline How will you benefit? & $\begin{array}{l}\text { Financial plan; Revenue Models; Market Rollout and } \\
\text { Penetration }\end{array}$ \\
\hline How can others benefit? & Investment / Partnership Opportunities \\
\hline
\end{tabular}

While this list of issues is by no means comprehensive, it's meant to be a good start to understanding the potential of your entrepreneurial idea. This course will give you the information necessary to transition between key questions to business planning in deepening your analysis of an entrepreneurial opportunity.

In undertaking this assignment, complete the following template in a maximum of two pages for submission to the instructor. As you proceed through the Key Questions, continuously refer back to the Key Questions to Business Planning Equivalents Table to get an idea of how the responses that you provide will eventually translate to more definitive, market driven factors. 
1. Who are you? - Provide your name and a few sentences on your background that provide a reference as to how you came up with your idea and why you might be able to serve the market with a product or service based on your idea.

2. What are you planning? - Provide a layman's description of the product or service that you'll be providing and the unique technology (or other differentiator) upon which your product or service will be based. Use limited figures or pictures as appropriate for clarity. Make sure to include a basic description of the features, function, and benefits of your product or service that will be valued by the customer.

3. Why can you do it better than anyone else? - There are many ways to differentiate products and services including unique technologies, distribution channels, marketing, low cost operations, etc. However, an entrepreneur needs to translate these unique aspects of the business opportunity / idea to a competitive advantage to be successful in attracting customers and fighting off the competition that already exists or will quickly emerge. Provide an overview of your expected competitive advantage - things that will make your product or service better, faster, cheaper, safer, etc.

4. Who cares, why do they care, and how much do they care? - This is the most primitive analysis of the customer base and market that your product or service will target. Customers will care because your product or service provides a unique benefit that is advantageous over competitive products or services in meeting their needs. Who are these customers, what are their problems that your product or service will solve, and is this a major or minor problem for them / opportunity for you. Why?

5. What do you need to get it done? - If your dream of bringing your product or service to market is to be achieved, certain barriers will need to be overcome; barriers such as technological hurdles, gaining access to your target markets, getting the customers to understand the value that your product or service will provide, etc. What will you need in order to overcome these barriers. This can take all forms from investment funds to strategic partnerships. While certain strategic investors, such as Venture Capitalists, can provide much more than cash in an investment round, it's important for you as an entrepreneur to understand that cash solves very few problems - the proper use of investment funds combined with the right people, timing, strategy, implementation plan, etc. can springboard a company to success.

6. How will you benefit? - How will you make money from this venture. Think hard about this as it's one of the areas that sink many start-up companies that don't take the time to understand what product or service benefit and service model the market is really willing to support.

7. How can others benefit? - If you engage other stakeholders such as employees, investors, strategic partners, etc., how will they see a return and payout from this venture. Remember that paper returns with no pathway for investors to realize a successful financial exit from the company, in whole or part, is typically useless to the investor. 


\section{Value Proposition Presentation Assignment}

As with everything in this course, this assignment is designed to build on what we've already covered and take you to the next level in refining and defining your opportunity. Up to this point you have:

- Gotten some understanding of where entrepreneurial ideas come from and how entrepreneurs think about these ideas in terms of market need, competitors, etc.

- Taken your individual ideas through a basic feasibility analysis to see if it may be an entrepreneurial opportunity

- Started to define your individual opportunity in terms of who, what, why, etc. based on the Idea Overview Assignment format

- Assessed your ideas through your team (company) and further refined one company idea / opportunity that you will all stand behind through the Team Idea Overview assignment

At the end of this course, you'll present your company opportunity through a business plan and presentation of your opportunity in class. The next step in getting to that point is to take the team opportunity you've developed and delineate the few key elements that really define the Value Proposition - the burning need for your offering that is economically substantial to a definable target market that your company and management team can uniquely serve with your product, service, or business model. As an entrepreneur, how well you can get stakeholders (investors, employees, partners, etc.) to buy into your Value Proposition will be key to your success in getting them behind your venture.

Your assignment is for your company to present to the instructor and the class your Value Proposition in a maximum of five minutes and a maximum of four PowerPoint slides (not inclusive of the cover slide). I would prefer that more than one member of the executive team present, but I'll leave it up to you for this assignment. The bottom line for this assignment is that I will be putting myself in the mindset of your target customers and investors and your presentation of your Value Proposition should excite me that you have an attractive offering that can uniquely fulfill my economically substantial needs and your management team can put together the business model to pull it off. 


\section{Final Business Plan and Final Presentation Assignments}

These two assignments are the culmination for this course and are designed to bring together everything that you've studied regarding creating and selling a vision and execution plan for an entrepreneurial venture. You'll be presenting your entrepreneurial opportunity through:

1. A written business plan

2. A business plan investor presentation

Business Plan - The business plan assignment provides you with an opportunity to create a 25-30 page (excluding appendices which should be limited) written summary of your entrepreneurial opportunity. This assignment challenges you to review the essential elements of a business plan that we've covered in this course and provide a summary of those elements that you feel are key to your offering. The instructor will grade your business plan based on the organization of the plan and how well you've researched, presented and explained key elements of your opportunity. Note that your grade will be heavily influenced by the level of detailed analysis you have in your plan. For instance, business plans with broad, high-level market and competitor analyses rather than specific detailed research and analysis will receive lower grades. "Fluff", buzzwords and phrases, and general, unconfirmed statements should be avoided and replaced with detailed analysis and statements / projections that have solid, data-based backing.

Business Plan Presentation - The business plan presentation assignment provides you with an opportunity to create and deliver a presentation of your entrepreneurial opportunity as you would for a group of investors. In this assignment, you'll take the essential elements of your business plan summary and present those in the most effective manner you can muster.

Your presentation will be judged on the compelling argument for investment that you present which will be comprised of presentation style (practice, practice, practice) as well as the investors' determination of the viability and attractiveness of the investment opportunity. The “judges” for your presentation are a set of 2-3 outside professionals who will be judging your presentations with me, but not your business plan summaries. The judges will be considering presentation style, substance, and business opportunity.

Presentations are a maximum of 7 minutes without audience interruption followed by a maximum of 5 minutes Q\&A from the judges. There is no limit on the number of slides you present, only time. After 7 minutes, you will stop speaking - no buffer. Immediately following the final presentation, I will ask each CEO to present their elevator pitch in reverse order of the presentations. 
Your team needs to decide what presentation format will get the judges excited about your opportunity. Each member will need to be at the front of the room during the presentation and available to answer questions, although all members do not need to present.

Assignment Submission - Your presentation slides and business plan summary must be submitted timely per the Sakai assignment deadline to the instructor in order to print hardcopies for the judges. I'd suggest that you submit it early in case the file size is a problem. When you submit your business plan summary and presentation slides, please include a paragraph or two in your assignment submission that lays out what your team feels were each individual member's relative contributions to the overall workload/productivity of the team throughout the course. I need only one input from each team on this. This will play a role in each person's individual course participation grade.

Company Acquisition - As stated at the beginning of the course, we're going to make this competitive. The judges will "buy" each company at a valuation that the judges deem appropriate within a valuation collar (maximum and minimum) that I'll establish prior to the Final Presentations. Based on the final buying price from the judges and the dilution that each company has experienced through the previous Investment Forum rounds, each company executive will have produced a return on the funds that they invested to start their companies. I'll calculate a Return on Investment (ROI) for each company based on each executive's individual financial return from the sale of their company (sales price of company times the executive's percentage ownership of the company at the time of sale) divided by the executive's initial investment in their companies for their initial shares. Each member of the company with the highest ROI will receive an A for the class and be excused from the final exam.

Additionally, the two investors with the highest ROI for the funds that they've invested in other companies in the Investment Forums will receive an A for the class and be excused from the Final Exam. I'll calculate this immediately after the Final Presentation as well.

The judges will take into account that they are being presented with different sized financial opportunities and risks. In order to assure total impartiality to all teams, I'm excusing myself from deciding on the final acquisition price of each company and will leave that to the outside judges. The outside judges will provide me with their feedback for each presentation and I'll combine that with my own judgment to establish each team's grade for the presentation. Obviously, this is a moot point for the winning team. 
Appendix B

Sample Course Student Companies Capitalization Table

\begin{tabular}{|c|c|c|c|c|c|c|c|}
\hline \multirow[b]{2}{*}{ Students } & \multicolumn{7}{|c|}{ Company Cap Tables (Founder Shares in Blue; Investor Shares in Red) } \\
\hline & Comp 1 & Comp 2 & Comp 3 & Comp 4 & Comp 5 & Comp 6 & Comp 7 \\
\hline Student 1 (Comp 1 Founder) & 40,000 & & 2,963 & 4,870 & 5,630 & & 5,000 \\
\hline Student 2 (Comp 1 Founder) & 40,000 & 4,298 & & 2,857 & 2,815 & & \\
\hline Student 3 (Comp 1 Founder) & 40,000 & 6,616 & & & 2,815 & & 6,916 \\
\hline Student 4 (Comp 1 Founder) & 40,000 & & 7,059 & & & & \\
\hline Student 5 (Comp 1 Founder) & 40,000 & 6,879 & & 7,117 & & & \\
\hline Student 6 (Comp 2 Founder) & & 40,000 & 3,939 & & & 11,717 & \\
\hline Student 7 (Comp 2 Founder) & 5,676 & 40,000 & & 2,130 & 3,554 & & \\
\hline Student 8 (Comp 2 Founder) & 3,478 & 40,000 & & 2,130 & 3,554 & 2,525 & \\
\hline Student 9 (Comp 2 Founder) & 4,976 & 40,000 & & 5,597 & & 2,525 & 5,000 \\
\hline Student 10 (Comp 2 Founder) & 7,874 & 40,000 & & 2,857 & & & 5,474 \\
\hline Student 11 (Comp 3 Founder) & 2,778 & 2,581 & 40,000 & & 3,554 & & 2,737 \\
\hline Student 12 (Comp 3 Founder) & & 2,149 & 40,000 & & 3,554 & & 5,000 \\
\hline Student 13 (Comp 3 Founder) & 2,778 & 2,581 & 40,000 & 2,857 & & & \\
\hline Student 14 (Comp 3 Founder) & 2,778 & 2,581 & 40,000 & 2,740 & & & 2,737 \\
\hline Student 15 (Comp 3 Founder) & & 1,886 & 40,000 & & 6,369 & & \\
\hline Student 16 (Comp 4 Founder) & & 4,298 & & 40,000 & 8,889 & & 2,737 \\
\hline Student 17 (Comp 4 Founder) & 4,976 & 2,149 & & 40,000 & & 6,667 & \\
\hline Student 18 (Comp 4 Founder) & & 1,886 & 1,891 & 40,000 & 7,259 & & 6,916 \\
\hline Student 19 (Comp 4 Founder) & 8,454 & 2,581 & & 40,000 & & 5,793 & \\
\hline Student 20 (Comp 4 Founder) & 5,676 & 2,149 & & 40,000 & 10,074 & & \\
\hline Student 21 (Comp 5 Founder) & 2,778 & & & 5,597 & 40,000 & & 2,737 \\
\hline Student 22 (Comp 5 Founder) & & & & & 40,000 & 9,127 & \\
\hline Student 23 (Comp 5 Founder) & & & & 4,987 & 40,000 & 5,793 & \\
\hline Student 24 (Comp 5 Founder) & 3,478 & & & 2,740 & 40,000 & 5,859 & \\
\hline Student 25 (Comp 5 Founder) & & 4,467 & 2,048 & 4,987 & 40,000 & & \\
\hline Student 26 (Comp 6 Founder) & 2,778 & & 5,011 & & & 40,000 & 5,000 \\
\hline Student 27 (Comp 6 Founder) & 5,676 & & & 2,740 & & 40,000 & 9,653 \\
\hline Student 28 (Comp 6 Founder) & & 2,581 & & 2,857 & & 40,000 & 4,653 \\
\hline Student 29 (Comp 6 Founder) & & 2,581 & & 2,740 & 4,444 & 40,000 & 4,653 \\
\hline Student 30 (Comp 6 Founder) & & & 5,011 & & & 40,000 & \\
\hline Student 31 (Comp 7 Founder) & 3,478 & & 4,096 & & 7,259 & 2,525 & 40,000 \\
\hline Student 32 (Comp 7 Founder) & 5,676 & & 5,830 & & & & 40,000 \\
\hline Student 33 (Comp 7 Founder) & & 1,886 & & 2,740 & & 11,717 & 40,000 \\
\hline Student 34 (Comp 7 Founder) & & & 4,854 & 2,130 & & 3,333 & 40,000 \\
\hline Student 35 (Comp 7 Founder) & 3,478 & 1,886 & 6,902 & & & & 40,000 \\
\hline Instructor & 9,734 & 18,363 & 4,854 & 13,699 & 23,104 & 9,935 & 35,326 \\
\hline Total Shares Outstanding & 302,606 & 279,125 & 282,824 & 294,549 & 330,494 & 307,289 & 314,189 \\
\hline
\end{tabular}


Shares Issued Per Unit

\begin{tabular}{|c|c|c|c|c|c|c|c|}
\hline \multicolumn{8}{|l|}{ Team Idea } \\
\hline Value Proposition & 3,478 & 2,581 & 2,963 & 2,857 & 4,444 & 3,333 & 5,000 \\
\hline Financials & 2,198 & 2,149 & 2,048 & 2,130 & 2,815 & 2,526 & 2,737 \\
\hline Business Plan & 2,776 & 1,886 & 1,892 & 2,740 & 3,554 & 3,269 & 1,916 \\
\hline Company Acquisition & 0 & 0 & 0 & 0 & 0 & 0 & 0 \\
\hline \multicolumn{8}{|c|}{ Total New Shares Issued } \\
\hline Team Idea & 200,000 & 200,000 & 200,000 & 200,000 & 200,000 & 200,000 & 200,000 \\
\hline Value Proposition & 41,739 & 30,968 & 35,556 & 34,286 & 53,333 & 40,000 & 60,000 \\
\hline Financials & 21,976 & 23,634 & 24,580 & 19,169 & 30,963 & 37,895 & 27,368 \\
\hline Business Plan & 38,863 & 24,517 & 22,703 & 41,101 & 46,198 & 29,424 & 26,821 \\
\hline Company Acquisition & 0 & 0 & 0 & 0 & 0 & 0 & 0 \\
\hline \multicolumn{8}{|c|}{ Post-Money Valuation (\$M) } \\
\hline Team Idea & 0.2 & 0.2 & 0.2 & 0.2 & 0.2 & 0.2 & 0.2 \\
\hline Value Proposition & 1.39 & 1.79 & 1.59 & 1.64 & 1.14 & 1.44 & 1.04 \\
\hline Financials & 2.4 & 2.37 & 2.54 & 2.38 & 2.02 & 2.2 & 2.1 \\
\hline Business Plan & 2.18 & 2.96 & 2.99 & 2.15 & 1.86 & 1.88 & 3.28 \\
\hline Company Acquisition & 2.5 & 4 & 3.5 & 3.5 & 2.5 & 3.5 & 2.5 \\
\hline \multicolumn{8}{|l|}{ Round Dilution (\%) } \\
\hline \multicolumn{8}{|l|}{ Team Idea } \\
\hline Value Proposition & $17 \%$ & $13 \%$ & $15 \%$ & $15 \%$ & $21 \%$ & $17 \%$ & $23 \%$ \\
\hline Financials & $8 \%$ & $9 \%$ & $9 \%$ & $8 \%$ & $11 \%$ & $14 \%$ & $10 \%$ \\
\hline Business Plan & $13 \%$ & $9 \%$ & $8 \%$ & $14 \%$ & $14 \%$ & $10 \%$ & $9 \%$ \\
\hline Company Acquisition & $0 \%$ & $0 \%$ & $0 \%$ & $0 \%$ & $0 \%$ & $0 \%$ & $0 \%$ \\
\hline \multicolumn{8}{|l|}{ Raise (\$M) } \\
\hline Team Idea & 0.2 & 0.2 & 0.2 & 0.2 & 0.2 & 0.2 & 0.2 \\
\hline Value Proposition & 0.24 & 0.24 & 0.24 & 0.24 & 0.24 & 0.24 & 0.24 \\
\hline Financials & 0.2 & 0.22 & 0.24 & 0.18 & 0.22 & 0.3 & 0.2 \\
\hline Business Plan & 0.28 & 0.26 & 0.24 & 0.3 & 0.26 & 0.18 & 0.28 \\
\hline Company Acquisition & 0 & 0 & 0 & 0 & 0 & 0 & 0 \\
\hline \multicolumn{8}{|c|}{ Pre-Money Valuation (\$M) } \\
\hline Team Idea & 0 & 0 & 0 & 0 & 0 & 0 & 0 \\
\hline Value Proposition & 1.15 & 1.55 & 1.35 & 1.4 & 0.9 & 1.2 & 0.8 \\
\hline Financials & 2.2 & 2.15 & 2.3 & 2.2 & 1.8 & 1.9 & 1.9 \\
\hline Business Plan & 1.9 & 2.7 & 2.75 & 1.85 & 1.6 & 1.7 & 3 \\
\hline Company Acquisition & 2.5 & 4.0 & 3.5 & 3.5 & 2.5 & 3.5 & 2.5 \\
\hline \multicolumn{8}{|c|}{ Pre-Money Shares Outstanding } \\
\hline \multicolumn{8}{|c|}{ Team Idea } \\
\hline Value Proposition & 200,000 & 200,000 & 200,000 & 200,000 & 200,000 & 200,000 & 200,000 \\
\hline Financials & 241,739 & 230,968 & 235,556 & 234,286 & 253,333 & 240,000 & 260,000 \\
\hline Business Plan & 263,715 & 254,602 & 260,135 & 253,455 & 284,296 & 277,895 & 287,368 \\
\hline Company Acquisition & 302,579 & 279,119 & 282,838 & 294,555 & 330,494 & 307,319 & 314,189 \\
\hline \multicolumn{8}{|l|}{ Unit Price (\$M) } \\
\hline \multicolumn{8}{|l|}{ Team Idea } \\
\hline Value Proposition & 0.02 & 0.02 & 0.02 & 0.02 & 0.02 & 0.02 & 0.02 \\
\hline Financials & 0.02 & 0.02 & 0.02 & 0.02 & 0.02 & 0.02 & 0.02 \\
\hline Business Plan & 0.02 & 0.02 & 0.02 & 0.02 & 0.02 & 0.02 & 0.02 \\
\hline Company Acquisition & 0 & 0 & 0 & 0 & 0 & 0 & 0 \\
\hline
\end{tabular}


$\underline{\text { Keys for this investment scenario: }}$

Team Idea / Company Inception - Nine companies (teams) of five students per company are assumed to be capitalized at inception with $\$ 200 \mathrm{k}$ split evenly among the founders. Founders are issued common stock at $\$ 1 /$ share. No outside capital is raised at company inception. Note that only seven companies and 35 students are shown for illustration purposes. The complete spreadsheet, including all calculations, is available from the author at esander@ufl.edu upon request.

Value Proposition Investment Forum - The capital raise for each company is set at $\$ 240 \mathrm{k}$ with each investor getting $\$ 40 \mathrm{k}$ of investment funds in units of $\$ 20 \mathrm{k}$. The instructor has $\$ 360 \mathrm{k}$ in $\$ 20 \mathrm{k}$ units. The valuation collar is initially set at $\$ 1-1.5 \mathrm{M}$ and then companies are allowed to bid up or down from there to close their investment round.

Financials and Business Plan Investment Forum - Each company's capital raise for these two capital rounds combined is set at $\$ 480 \mathrm{k}$ with each investor getting $\$ 80 \mathrm{k}$ in investment funds in units of $\$ 20 \mathrm{k}$. The instructor has $\$ 720 \mathrm{k}$ in $\$ 20 \mathrm{k}$ units. The initial pre-money collar for this round is set at $\$ 1-3 \mathrm{M}$ and companies are then allowed to bid up or down from there.

Company Acquisition - No incremental capital is raised on the company acquisition. Pre-money equals post-money valuation. The value of the acquisition is set by external investors (judges) within a collar of $\$ 1-4 \mathrm{M}$.

Return on Investment calculations (not shown) -

- Company Founder ROI is calculated as the terminal value of the founder shares held at the time of the acquisition [(Acquisition Price * Founder Ownership Percentage) divided by each founder's initial investment at company inception ( $\$ 40 \mathrm{k}$ in this scenario)]. It should be noted that the founder ROI scenario will be valid for scenarios of different numbers of founders in different companies as long as founders evenly contribute to the initial investment in their company and receive stock at equivalent share prices and different companies are capitalized evenly.

- Investor ROI is calculated as [the summation of the terminal value of the investors shares held at the time of the acquisition (Invested Company Acquisition Price * Investor Ownership Percentage) divided by the total investment in other companies throughout the semester ( $\$ 120 \mathrm{k}$ in this scenario)]. Note that this calculation of ROI is for the students as investors in other companies and does not include the ROI in their investment in their own company, for which they are judged separately as shown above. 
Bibliography

${ }^{\mathrm{i}}$ Volkmann, C., Wilson, K., Mariotti, S., Rabuzzi, D., Vyakarnam, S., Sepulveda, A. (2009), "Educating the Next Wave of Entrepreneurs Unlocking entrepreneurial capabilities to meet the global challenges of the 21st Century - A Report of the Global Education Initiative”, World Economic Forum, Switzerland, April 2009

${ }^{i i}$ National Academy of Engineering: Engineering Grand Challenges. Accessed March 5, 2011 at www.engineeringchallenges.org.

iii Wadhwa, V., Freeman, R., and Rissing, B. Education and Tech Entrepreneurship, The Ewing Marion Kaufman Foundation. May 2008

${ }^{\text {iv }}$ ABET Accreditation Criteria accessed March 5, 2011 at www.abet.org.

${ }^{v}$ Bradley, W., Grinols, A., Blalock, G., Jordan, W., Leman, G., and Fry, C. 2008. Incorporating Global Entrepreneurship Courses into an Engineering Curriculum. NCIIA $12^{\text {th }}$ Annual Meeting Proceedings, NCIIA $12^{\text {th }}$ Annual Meeting: Getting to the Point, ideas, process, products. 87-94.

${ }^{\text {vi }}$ ASEE (American Society for Engineering Education). 2009. Profiles of Engineering and Engineering Technology Colleges. Washington, D.C.: ASEE.

vii AUTM (Association of University Technology Managers. 2009. U.S. Licensing Activity Survey: FY2009. Chicago, IL: AUTM.

viii Beaury, R., Boyer, P., and Kisenwether, E. 2010. Using Live Cases in Problem-Based Entrepreneurship Learning. NCIIA $14^{\text {th }}$ Annual Meeting Publications accessed March 5, 2011 at http://nciia.org/network/conference/2010/papers.

${ }^{\text {ix }}$ Kuratko, D. F. (2005), The Emergence of Entrepreneurship Education: Development, Trends, and Challenges. Entrepreneurship Theory and Practice, 29: 577-598. doi: 10.1111/j.1540-6520.2005.00099.x

${ }^{x}$ Neck, H. M. and Greene, P. G. (2011), Entrepreneurship Education: Known Worlds and New Frontiers. Journal of Small Business Management, 49: 55-70. doi: 10.1111/j.1540-627X.2010.00314.x

${ }^{x i}$ Phillips, K., and Jackowski, M. 2010. Beyond the Business Plan: Building Implementation into an Entrepreneurship Curriculum. NCIIA 14 ${ }^{\text {th }}$ Annual Meeting Publications accessed March 5, 2011 at http://nciia.org/network/conference/2010/papers.

xii Pittaway L., Cope J., Simulating entrepreneurial learning: Integrating experiential and collaborative approaches to learning (2007) Management Learning, 38 (2), pp. 211-233.

xiii Silvernagel, S. and Clement, T. 2010. Core Content in Entrepreneurship Higher Education Curriculum: A Literature Review and Feasibility Influence Model (FIM) Proposal. Midwest Academy of Management 2010 Annual Conference Proceedings, Strategizing, Leading and Motivating: Achieving a "hat trick" in Challenging Times.

xiv Drummond, C. K. 2010. Team-Based Learning to Enhance Critical Thinking Skills in Entrepreneurship Education. Allied Academies International Conference 2010. Proceedings of the Academy of Entrepreneurship, Volume 16, Number 2. pp. 18-22. 